\title{
Procalcitonin to allow early detection of sepsis and multiple organ failure in severe multiple trauma: beware of some confounders
}

\author{
Patrick M. Honore*, Christina David, Rachid Attou, Sebastien Redant, Andrea Gallerani and David De Bels
}

AlRawahi et al. concluded that sepsis and multiple organ failure (MOF) are the predominant cause of late death in severe multiple trauma (MT) [1]. They suggested that repeated measures of procalcitonin (PCT) during disease course may allow for early recognition of septic complications and detection of multiple organ failure (MOF), resulting in earlier therapeutic decisions and an impact on survival and improve outcomes [1].

We would like to make some comments. A recent meta-analysis evaluating more than 26,000 MT patients revealed a pooled incidence of acute kidney injury (AKI) in MT of more than 20\% [2]. In addition, in a further breakdown of the A KI stages, over $40 \%$ of these patients were classified with more severe forms of AKI (RIFLE I or F or stages 2-3) [2] suggesting a probable use of renal replacement therapy (RRT) between 5 and 10\% [2]. This incidence could be even higher (up to 20\%) if MT is complicated by sepsis and MOF [3]. If we apply the same trends for the study of AlRawahi et al., the incidence of RRT in MT with sepsis and MOF could have an impact upon the reliability of the PCT level under those conditions. PCT has an approximate molecular weight of $14.5 \mathrm{kDa}$ [4]. The contemporary continuous RRT (CRRT) membranes are able to remove molecules as large as $35 \mathrm{kDa}$ [4]. Hence, most of the PCT mass will be eliminated by convective flow [4], but adsorption also contributes to the elimination if using new highly adsorptive membranes (HAM) [5]. Accordingly, an imbalance between the use of CRRT in the two cohorts (MT alone or MT with sepsis and MOF) will have an important impact upon the values of PCT in each cohort but more so in

\footnotetext{
* Correspondence: Patrick.Honore@CHU-Brugmann.be

This comment refers to the article available at https://doi.org/10.1186/ s13054-019-2669-1.

ICU Department, Centre Hospitalier Universitaire Brugmann, Place Van Gehuchtenplein 4, 1020 Brussels, Belgium
}

the MT cohort with sepsis and MOF. PCT levels may therefore be affected not only by the complications of MT but also by the incidence of RRT. In conclusion, we believe there is a critical need for a future study with a focus on the performance of the currently known biomarkers among patients receiving CRRT [5].

\section{Abbreviations \\ AKI: Acute kidney injury; CRRT: Continuous renal replacement therapy; HAM: Highly adsorptive membranes; MOF: Multiple organ failure; MT: Multiple trauma; PCT: Procalcitonin; RRT: Renal replacement therapy \\ Acknowledgements \\ We would like to thank Dr. Melissa Jackson for the critical review and complete editing process of the letter.}

\section{Authors' contributions}

$\mathrm{PMH}, \mathrm{SR}$, and DDB designed the paper. All authors participated in the drafting of the manuscript. All authors have read and approved the final version.

\section{Funding}

None.

\section{Availability of data and materials Not applicable.}

Ethics approval and consent to participate Not applicable.

\section{Consent for publication}

Not applicable.

\section{Competing interests}

The authors declare that they have no competing interests.

Received: 12 December 2019 Accepted: 1 January 2020

Published online: 07 January 2020

\section{References \\ 1. AlRawahi AN, AlHinai FA, Doig CJ, et al. The prognostic value of serum procalcitonin measurements in critically injured patients: a systematic review. Crit Care. 2019;23:390. https://doi.org/10.1186/s13054-019-2669-1. \\ 2. Haines RW, Fowler AJ, Kirwan CJ, Prowle JR. The incidence and associations of acute kidney injury in trauma patients admitted to critical care: a systematic review and meta-analysis. J Trauma Acute Care Surg. 2019;86(1): 141-7. https://doi.org/10.1097/TA.0000000000002085.}


3. Peters E, Antonelli M, Wittebole X, Nanchal R, François B, Sakr Y, et al. A worldwide multicentre evaluation of the influence of deterioration or improvement of acute kidney injury on clinical outcome in critically ill patients with and without sepsis at ICU admission: results from the Intensive Care Over Nations audit. Crit Care. 2018;22(1):188. https://doi.org/ 10.1186/s13054-018-2112-z.

4. Level C, Chauveau P, Guisset O, Cazin MC, Lasseur C, Gabinsky C, et al. Mass transfer, clearance and plasma concentration of procalcitonin during continuous venovenous hemofiltration in patients with septic shock and acute oliguric renal failure. Crit Care. 2003;6:R160-6.

5. Honoré PM, Jacobs R, De Waele E, Van Gorp V, Spapen HD. Evaluating sepsis during continuous dialysis: are biomarkers still valid? Blood Purif. 2014;38(2):104-5. https://doi.org/10.1159/000363497 Epub 2014 Oct 17.

\section{Publisher's Note}

Springer Nature remains neutral with regard to jurisdictional claims in published maps and institutional affiliations. 